\title{
Quality characteristics and antioxidant activity of onion peel extracts by extraction methods
}

\author{
Da-Som Jeong, Da-Ae Back, Yu-Ri Kwon, Gi-Man Kwon, Kwang-Sup Youn* \\ Department of Food Science and Technology, Catholic University of Daegu, Gyeongsan 712-702, Korea
}

\section{추출방법에 따른 양파껍질 추출물의 품질특성 및 항산화활성 비교}

\author{
정다솜 · 백다애 · 권유리 · 권기만 · 윤광섭* \\ 대구가톨릭대학교 식품공학과
}

\begin{abstract}
This study was conducted to evaluate the antioxidant activities and the quality characteristics of $70 \%$ ethanol extracts from onion peels with different extraction methods (autoclave extraction, AE; low temperature high pressure extraction, LTPE; reflux extraction, RE; and stirrer extraction, SE). The yields of AE, LTPE, RE and SE were $9.00 \%, 5.39 \%$, $13.21 \%$ and $12.41 \%$, respectively. The total polyphenol and flavonoid contents in the AE were significantly higher than in the other extracts. The DPPH radical scavenging abilities with a concentration of $100 \mathrm{mg} \%(\mathrm{w} / \mathrm{v})$ were : AE, 28.9\%; RE, 26.07\%; LTPE, 24.35\%; and SE, 19.53\%. The ABTS radical scavenging ability and the nitrite scavenging activity showed the same tendency as that of the DPPH radical scavenging ability. The angiotensin - converting enzyme (ACE) inhibitory activities of the LTPE and AE were higher than those of the RE and SE. The a-Glucosidase inhibitory activity of the RE was higher than that of the extracts with other extraction methods. The nitrite scavenging activities with a concentration of $10 \mathrm{mg} / \mathrm{mL}$ were: AE. 33.97\%; RE, 35.47\%; LTPE, $21.86 \%$; and SE, $21.71 \%$. The ferrous ion chelating activity of the LTPE $(54.73 \%)$ was significantly higher than that of the other extracts. These results suggest that $\mathrm{AE}$ is the superior method for the enhancement of anti-oxidant activity, and onion peel can be used as a natural antioxidant material for health foods and can be a good ingredient of functional foods.
\end{abstract}

Key words : Allium cepa L. peels, quality characteristics, antioxidant activity, extraction method

\section{서 론}

최근 가공 산업의 발달로 각종 농산물들의 상당량이 가 공처리 되고 있으나 제조 과정 중에 대량의 부산물이 발생 하고 있으며, 이를 자원화 하려는 연구가 다각적으로 이루 어지고 있다(1). 특히 부산물 중에는 천연 항산화 물질인 폴리페놀을 다량 함유하고 있어 이를 활용한 고부가가치의 기능성 소재 관련 연구가 주목을 받고 있다.

*Corresponding author. E-mail : ksyoun@cu.ac.kr

Phone : 82-53-850-3209, Fax : 82-53-850-3209

Received 26 January 2015; Revised 8 April 2015; Accepted 13 April 2015.

Copyright (c) The Korean Society of Food Preservation. All rights reserved.
양파(Allium cepa L.)는 백합과에 속하는 다년초로써 quercetin, quercitrin, rutin 등의 flavonoid 물질이 풍부한 대 표적인 식품으로 알려져있다. 특히 양파의 주된 성분인 quercetin은 flavonoid 성분으로써 벤젠환의 탄소에 -OH기 와 2 번 탄소와 3 번 탄소 사이의 이중결합, 4 번 탄소위치에 carbonyl기, 그리고 A-ring와 B-ring에 결합되어 있는 - $\mathrm{OH}$ 기 에 의해서 항산화 활성을 갖는 구조를 가지고 있어, 활성산 소의 산화활동을 억제하거나 제거하는 능력이 매우 강하여 $(2,3)$ 식품의 산화 방지제로 사용되고 있다. 또한 뇌세포의 보호기능(4)과 혈당상승억제(5)에도 효능이 있다고 알려져 있다. 특히 Kang 등(6)의 연구결과에 따르면 quercetin 함량 이 양파껍질을 포함한 비가식 부위가 $208.82 \mathrm{mg} \%$ 로 가식부 위의 $2.26 \mathrm{mg} \%$ 보다 약 90 배 이상 많이 함유되어있다고 보고되었다. 많은 양의 유용성분들이 양파껍질에 함유되어 
있으나 양파 육질에 대한 연구가 대부분으로 양파껍질에 대한 연구는 미비한 실정이다. 또한 양파껍질에 대한 연구 는 주로 양파껍질 자체의 품질특성이나 생리특성에 관한 것으로 추출방법에 따른 품질특성 및 생리활성에 관한 연구 는 진행되지 못하고 있다.

식물의 기능성물질을 추출하기 위한 대표적인 방법으로 는 환류냉각추출법이 많이 사용되고 있으나 환류냉각추출 은 열에 의한 유용성분 파괴, 단백질 변이, 가용성분 위주의 추출, 장시간의 추출 및 낮은 추출효율로 인한 에너지 소비 등과 같은 단점이 있으므로 천연물의 추출효율을 증가시키 기 위하여 고온고압추출, 저온고압추출, 초음파추출, 에탄 올추출 등 여러 가지 추출방법들이 이용되고 있다 $(7,8)$.

따라서 본 연구에서는 양파껍질의 이용가치를 향상시키 기 위한 가압가열추출, 저온고압추출, 환류냉각추출, 상온 교반추출을 조건으로 하여 양파껍질 추출물을 제조한 후 각 추출물의 품질특성 및 항산화 활성을 비교하여 가장 효과적인 추출방법을 제시하고, 산업화에 적용할 방법을 모색 및 기능성 식품 소재를 개발하는 기초자료로 활용하고 자 한다.

\section{재료 및 방법}

재 료

본 실험에서 사용된 양파껍질은 이강산 닷컴 (http://egangsan.com)에서 2013년 10월 일괄 구매하여 사용 하였으며, 흙과 먼지 등의 이물질을 제거하여 균질기(IKA A11 basic, IKA Werke GmbH \& Co., KG, Staufen, Germany) 를 사용하여 분쇄한 후 $40 \mathrm{mesh}$ 의 분말을 $-50^{\circ} \mathrm{C}$ 에 보관하 면서 실험에 사용하였다.

\section{추출물 제조}

양파껍질 추출방법은 분쇄시료 $50 \mathrm{~g}$ 에 15 배의 $70 \%$ ethanol을 가한 후 가압가열추출, 저온고압추출, 환류냉각 추출, 상온교반추출 방법으로 추출물을 제조하였다. 가압 가열추출은 autoclave(DF-100A, DOORI Scientific Co., Gyeonggi, Korea)를 이용하여 $121^{\circ} \mathrm{C}$ 에서 15 분 동안 추출하 였으며, 저온고압추출은 rapid extractor(FT110, Benchtop rapid extractor, ARMFIELD, England)를 이용하여 실온에서 2시간 동안 $8.0 \mathrm{bar}$ 의 압력 하에서 2 회 반복 추출하였다. 환류냉각추출은 분쇄시료와 용매를 넣은 용기에 냉각관을 부착하여 $60^{\circ} \mathrm{C}$ 의 맨틀 상에서 3시간씩 3회 반복 추출하였고 상온교반추출은 $25 \pm 2^{\circ} \mathrm{C}$ 의 실온에서 교반기(Wise Stir SMHS-3, DAIHAN Scientific Co., Seoul, Korea)를 이용하여 $250 \mathrm{rpm}$ 으로 24시간 추출하였다. 각각의 추출물은 rotary vacuum evaporator(rotary vacuum evaporator N-N series, Eyela, Tokyo, Japan)로 감압농축한 후에 동결건조(FD
SFDSM12, Samwon, Korea)하여 분말 시료를 제조하였으 며, $-50^{\circ} \mathrm{C}$ 에 보관하면서 실험에 사용하였다.

수 율

각 추출물들의 수율은 추출액을 동결 건조시켜 건물 중 량을 구한 다음 추출액 조제에 사용한 원료 건물량에 대한 백분율로 나타내었다.

색 도

색도는 색차계(Chromameter CR-200, Minolta, Tokyo, Japan)로 측정하였으며, 밝기를 나타내는 L(lightness), 적색 도를 나타내는 $\mathrm{a}$ (redness), 황색도를 나타내는 b(yellowness) 및 $\mathrm{H}^{\circ}$ (hue angle value)를 측정하였다.

\section{폴리페놀 함량 측정}

Dewanto 등(9)의 방법에 따라 시료 $100 \mu \mathrm{L}$ 에 $2 \%$ sodium carbonate $2 \mathrm{~mL}$ 과 50\% Folin-Ciocalteu reagent $100 \mu \mathrm{L}$ 을 가한 후 $720 \mathrm{~nm}$ 에서 흡광도를 측정하였으며, gallic acid(Sigma-Aldrich Co., St. Louis, MO, USA)의 검량선에 의하여 함량을 산출하였다.

\section{플라보노이드 함량 측정}

Abdel-Hameed(10)의 방법에 따라 시료 $100 \mathrm{~mL}$ 에 5\% sodium nitrite $0.15 \mathrm{~mL}$ 을 가한 후 $25^{\circ} \mathrm{C}$ 에서 6 분간 방치한 다음 $10 \%$ aluminium chloride $0.3 \mathrm{~mL}$ 를 가하여 $25^{\circ} \mathrm{C}$ 에서 5 분간 방치하였다. 다음 $1 \mathrm{~N} \mathrm{NaOH} 1 \mathrm{~mL}$ 를 가하고 vortex상 에서 가한 후 $510 \mathrm{~nm}$ 에서 흡광도를 측정하였으며 rutin hydrate(Sigma-Aldrich Co., USA)의 검량선에 의하여 함량 을 산출하였다.

\section{$\mathrm{DPPH}$ radical 소거활성 측정}

DPPH radical 소거활성은 Blois(11)의 방법에 의하여 실 험하였다. 시료 $0.2 \mathrm{~mL}$ 에 $0.4 \mathrm{mM} \mathrm{DPPH}(1,1$-diphenyl2-picryl-hydrazyl) 용액 $0.8 \mathrm{~mL}$ 를 가하여 10 분간 방치한 다 음 $525 \mathrm{~nm}$ 에서 분광광도계(UV-1650PC, Shimadzu, Kyoto, Japan)를 이용하여 흡광도의 변화를 측정하였으며, electron donating ability(\%)=100-[(OD of sample/OD of control) $\times 100]$ 에 의하여 활성도를 산출하였다.

\section{ABTS radical 소거활성 측정}

$\operatorname{Re}$ 등(12)의 방법에 따라 $7.4 \mathrm{mM} \mathrm{ABTS}[2,2$ '-azinobis(3-ethylbenzothiazoline-6-sulfonic acid) diammonium salt] 와 $2.6 \mathrm{mM}$ potassium persulfate를 혼합하여 실온 - 암소에서 24시간 동안 방치하여 radical을 형성시킨 다음 실험 직전에 ABTS 용액을 $732 \mathrm{~nm}$ 에서 흡광도가 $0.700 \pm 0.030$ 이 되도록 phosphate buffer saline(PBS, pH 7.4)로 희석하여 사용하였 다. 희석된 용액 $950 \mu \mathrm{L}$ 에 추출물 $50 \mu \mathrm{L}$ 를 가하여 암소에서 10 분간 반응시킨 후 $732 \mathrm{~nm}$ 에서 흡광도를 측정하였으며 
계산식, ABTS radical scavenging ability $(\%)=100-[(\mathrm{OD}$ of sample/OD of control) $\times 100]$ 에 의하여 활성을 산출하였다.

\section{$\mathrm{a}-$ Glucosidase 저해 효과 측정}

$\operatorname{Kim}$ 등(13)의 방법에 따라 추출물 $0.05 \mathrm{~mL}, 1 \mathrm{uint} / \mathrm{mL}$ a-glucosidase $0.05 \mathrm{~mL}$ 과 $200 \mathrm{mM}$ potassium phosphate buffer(pH 7.0) $0.05 \mathrm{~mL}$ 을 잘 혼합하여 $37^{\circ} \mathrm{C}$ 에서 10 분간 전처리 하였다. 그 다음 $3 \mathrm{mM} \rho \mathrm{NPG}$ ( $\rho$-nitrophenyl $\mathrm{a}$ -D-glucopyranoside) $0.1 \mathrm{~mL}$ 을 첨가하여 $37^{\circ} \mathrm{C}$ 에서 10 분간 반응시킨 후 $0.1 \mathrm{M} \mathrm{Na}_{2} \mathrm{CO}_{3} 0.75 \mathrm{~mL}$ 로 반응을 정지시켜 $405 \mathrm{~nm}$ 에서 흡광도를 측정하였으며, 효과는 a-glucosidase inhibition (\%)=[1-(CAbs-SAbs)/(CAbs-BAbs)] $\times 100$ : "CAbs; 대조구 흡광도, SAbs; 시료 흡광도, BAbs; 시료 무첨가구의 흡광도"에 의하여 산출하였다.

Angiotensin I converting enzyme(ACE) 저해 효과 측정 $\mathrm{ACE}$ 저해 효과는 Cushman과 Chung의 방법(14)을 변형 하여 측정하였으며, 조효소액은 rabbit lung acetone powder(Sigma-Aldrich Co.)를 $0.2 \mathrm{~g} / 10 \mathrm{~mL}(\mathrm{w} / \mathrm{v})$ 의 농도로 $4^{\circ} \mathrm{C}$ 에서 24 시간 추출한 후, 원심분리 $\left(4^{\circ} \mathrm{C}, 4,000 \mathrm{rpm}, 40\right.$ $\mathrm{min}$ )하여 상등액을 조효소액으로 사용하였다. 기질은 0.3 $\mathrm{M} \mathrm{NaCl}$ 이 함유된 $0.1 \mathrm{M}$ sodium borate buffer(pH 8.3)에 HLL(hippuryl-histidyl-leucine, Sigma-Aldrich Co.)을 5 $\mathrm{mg} / \mathrm{mL}(\mathrm{w} / \mathrm{v})$ 의 농도로 녹인 후 기질로 사용하였다. $\mathrm{ACE}$ 저해 활성은 시료 $50 \mu \mathrm{L}$ 를 가한 다음 $37^{\circ} \mathrm{C}$ 에서 5 분간 예비 반응을 시킨 후, 기질 $50 \mu \mathrm{L}$ 를 가하고 다시 $37^{\circ} \mathrm{C}$ 에서 1 시간 반응시켰다. 다음 $1 \mathrm{~N} \mathrm{HCl} 150 \mu \mathrm{L}$ 를 가하여 반응을 정지시 키고 $750 \mu \mathrm{L}$ 의 ethyl acetate를 가한 후, 1 분간 교반하고 원심분리 $\left(4^{\circ} \mathrm{C}, 5,000 \mathrm{rpm}, 10 \mathrm{~min}\right)$ 한 다음 $500 \mu \mathrm{L}$ 의 상등액 을 얻었다. 이 상등액을 $120^{\circ} \mathrm{C}$ 에서 30 분간 완전히 건조시켜 $2 \mathrm{~mL}$ 의 methanol을 넣은 후 $228 \mathrm{~nm}$ 에서 흡광도를 측정하였 다. 대조구로서는 추출물 대신 추출용매 $50 \mu \mathrm{L}$ 을 가하여 측정하였으며, 저해 효과는 계산식 ACE inhibition(\%)= [1-(CAbs-SAbs)/(CAbs-BAbs)]×100: "CAbs, 대조구 흡광 도; SAbs, 시료 흡광도; $\mathrm{BAbs}$, 시료 무 첨가구의 흡광도”에 의하여 산출하였다.

\section{아질산염 소거활성 측정}

Kato 등(15)의 방법에 따라 $1 \mathrm{mM} \mathrm{NaNO} 2$ 용액 $1 \mathrm{~mL}$ 에 추출물 $1 \mathrm{~mL}$ 를 가하고 $0.1 \mathrm{~N} \mathrm{HCl}$ 과 $0.2 \mathrm{M}$ citrate buffer(pH $2.5)$ 를 가하여 총 부피를 $10 \mathrm{~mL}$ 를 취하여 $2 \%$ 초산용액 $3 \mathrm{~mL}$ 와 $30 \%$ 초산용액으로 용해한 Griess reagent $(1 \%$ sulfanilic acid : $1 \%$ naphthylamine $=1: 1) 0.4 \mathrm{~mL}$ 를 순차적으 로 가한 후 실온에서 15 분간 방치, $520 \mathrm{~nm}$ 에서 흡광도를 측정하였다. 대조구는 Griess reagent 대신 증류수를 사용하 였으며, 계산식 nitrite scavenging activity $(\%)=100-[\mathrm{OD}$ of acnple/OD of control] $\times 100]$ 에 의하여 산출하였다.
철 이온 $\left(\mathrm{Fe}^{2+}\right)$ 에 대한 chelating 활성 측정

Yen 등(16)의 방법에 따라 시액 $1 \mathrm{~mL}, 80 \%$ ethanol 0.08 $\mathrm{mL}, 2 \mathrm{mM} \mathrm{FeCl} 2 \cdot 4 \mathrm{H}_{2} \mathrm{O}$ [iron( $(\mathrm{I})$ chlotide tetrahydrate] 용 액 $0.1 \mathrm{~mL}, 5 \mathrm{mM}$ ferrozine[3-(2-pyridyl)- 5,6-diphenyl1,2,4-rtiazine - 4',4"=disulronic acid]용액 $0.1 \mathrm{~mL}$ 를 첨가한 다음 혼합하여 실온에서 10 분간 반응시킨 후 $562 \mathrm{~nm}$ 에서 흡광도를 측정하였다. 대조구는 대표적 chelating agent인 $\mathrm{EDTA}$ 를 사용하였으며 계산식, ferrous ion chelating $\operatorname{effect}(\%)=100=[(\mathrm{OD}$ of sample/OD of control $) \times 100]$ 에 의하 여 산출하였다.

\section{통계처리}

모든 실험은 3회 반복으로 행하여 평균치와 표준편차로 나타내었고, 유의성 검증은 SPSS(Statistical Package for Social Sciences, 12, SPSS Inc., Chicago, IL, USA) software package program을 이용하여 Duncan's multiple range test를 행하였다 $(\mathrm{p}<0.05)$.

\section{결과 및 고찰}

\section{수율 및 색도}

추출방법에 따른 양파껍질 $70 \%$ 에탄올 추출물의 추출 수율 및 색도는 Table 1 과 같다. 추출수율은 $\mathrm{AE}$ (autoclave extraction)가 $13.21 \%$ 로 가장 높았으며, $\mathrm{SE}$ (stirrer extraction), $\mathrm{RE}$ (reflux extraction) 및 LTPE(low temperature high pressure extraction)가 각각 $12.41 \%, 9.00 \%, 5.39 \%$ 로 높은 수율을 나타내었다. 특히 $\mathrm{SE}$ 와 $\mathrm{RE}$ 의 경우 LTPE의 수율과 2 배 이상 의 차이를 보였다. 이는 Kwon 등(17)의 추출방법에 따른 쇠비름의 추출 수율이 환류냉각추출 및 가압가열추출이 저온고압추출에 비해 약 3 배 정도의 수율을 나타낸 것과 일치하였다. 환류냉각추출과 가압가열추출에서 높은 수율 을 나타내는 것은 열처리 공정에 의하여 불용성 세포벽의 수용화에 의해 수용성 식이섬유가 증가되는 현상과 더불 어, 수용화 과정 중에 식물조직의 구조적인 변화에 따라 불용성 식물의 세포벽으로부터 식이섬유 성분의 용해가 용이해짐에 따른 결과로 사료된다(18). 또한 Kang 등(19)의 연구에서 양파껍질의 착즙 전 가열온도에 따른 추출수율을 비교한 결과 $100^{\circ} \mathrm{C}$ 가열 했을 때 보다 낮은 온도인 $80^{\circ} \mathrm{C}$ 에서 가열했을 때의 수율이 더 높았던 것으로 미루어 볼 때 $121^{\circ} \mathrm{C}$ 에서 추출을 하는 가압가열 추출물의 경우 고온에서 양파껍 질의 유용성분이 파괴가 되어 비교적 낮은 온도에서 추출하 는 환류냉각추출과 상온교반추출에 비해 낮은 수율을 나타 낸 것으로 사료된다. 색도의 경우 밝기를 나타내는 $\mathrm{L}$ 값과 채도를 나타내는 chroma value의 경우 추출방법에 따른 차 이가 나타나지 않았다. 반면 적색도를 나타내는 a값은 상온 교반추출과 환류냉각추출은 비슷한 값을 보였으나 압을 
Table 1. Yields and Hunter's color values of the onion peel extracts according to the extraction method

\begin{tabular}{ccccccc}
\hline \multirow{2}{*}{ Samples ${ }^{1)}$} & Yields & \multicolumn{5}{c}{ Hunter's color value } \\
\cline { 3 - 7 } & $(\%)$ & $\begin{array}{c}\mathrm{L} \\
\text { (lightness) }\end{array}$ & $\begin{array}{c}\mathrm{a} \\
\text { (redness) }\end{array}$ & $\mathrm{b}$ (yellowness) & $\begin{array}{c}\mathrm{H} \\
\text { (hue angle) }\end{array}$ & Chroma value \\
\hline $\mathrm{AE}$ & $9.00^{\mathrm{c}}$ & $46.25 \pm 0.15^{2) \mathrm{b} 3)}$ & $16.12 \pm 0.12^{\mathrm{a}}$ & $10.45 \pm 0.17^{\mathrm{c}}$ & $56.80 \pm 0.10^{\mathrm{c}}$ & $19.21 \pm 0.04^{\mathrm{a}}$ \\
$\mathrm{LTPE}$ & $5.39^{\mathrm{d}}$ & $43.42 \pm 0.69^{\mathrm{c}}$ & $10.76 \pm 0.35^{\mathrm{b}}$ & $14.03 \pm 0.32^{\mathrm{b}}$ & $52.60 \pm 0.53^{\mathrm{d}}$ & $17.68 \pm 0.45^{\mathrm{b}}$ \\
$\mathrm{RE}$ & $13.21^{\mathrm{a}}$ & $44.27 \pm 0.88^{\mathrm{c}}$ & $8.93 \pm 0.35^{\mathrm{c}}$ & $14.30 \pm 0.72^{\mathrm{b}}$ & $58.03 \pm 0.31^{\mathrm{b}}$ & $16.86 \pm 0.79^{\mathrm{c}}$ \\
$\mathrm{SE}$ & $12.41^{\mathrm{b}}$ & $49.09 \pm 0.41^{\mathrm{a}}$ & $8.54 \pm 0.17^{\mathrm{c}}$ & $15.80 \pm 0.26^{\mathrm{a}}$ & $61.66 \pm 0.31^{\mathrm{c}}$ & $17.96 \pm 0.29^{\mathrm{b}}$ \\
\hline
\end{tabular}

${ }^{1)} \mathrm{AE}$, autoclave extraction; LTPE, low temperature high pressure extraction; RE, reflux extraction; SE, stirrer extraction.

${ }^{2)}$ Values are mean \pm standard deviation of triplicate determinations.

${ }^{3}$ Different superscripts within a column $(\mathrm{a}-\mathrm{d})$ indicate significant differences $(\mathrm{p}<0.05)$.

가한 저온고압추출의 경우 증가하였으며 열과 압을 모두 가한 가압가열추출의 경우 상온교반추출과 환류냉각추출 의 2 배 높은 값을 나타내었으며, 황색도를 나타내는 $b$ 값은 가압가열추출이 다른 추출방법에 비하여 감소하는 경향을 나타내었다.

\section{폴리페놀 및 플라보노이드함량}

페놀화합물(polyphenolics)은 자연계에 널리 존재하는 천 연색소로서 주로 액포 및 세포막에서 유리형, 에스테르형 또는 결합형으로 존재하며(20), 항암을 비롯하여 항고혈압, 항염증, 항당뇨 항산화 및 항노화 등 여러 생리적 및 약리적 효능이 있는 것으로 밝혀져 왔다(21). 특히 유리라디컬(free radical)을 소거하는 항산화 활성이 높은 것으로 알려져 있 다(22).

추출방법에 따른 양파껍질 추출물의 폴리페놀 및 플라보 노이드의 함량을 측정한 결과는 Table 2 와 같다. 각 추출물 의 폴리페놀 함량은 가압가열추출 $(209.99 \mathrm{mg} / \mathrm{g})$ 이 가장 높 은 함량을 나타내었으며, 환류냉각추출 $(178.24 \mathrm{mg} / \mathrm{g})$, 저온 고압추출 $(176.01 \mathrm{mg} / \mathrm{g})$, 상온교반 $(140.14 \mathrm{mg} / \mathrm{g})$ 순으로 높 은 함량을 나타냈다. 플라보노이드 함량 또한 가압가열추 출 $(25.00 \mathrm{mg} / \mathrm{g})$, 환류냉각추출 $(23.30 \mathrm{mg} / \mathrm{g})$, 저온고압추출 $(20.32 \mathrm{mg} / \mathrm{g})$, 상온교반 $(20.09 \mathrm{mg} / \mathrm{g})$ 순으로 높은 함량을 나 타내었다. 폴리페놀의 경우 고온과 고압 하에서 불용성 성 분들이 가용화 됨에 따라 막 투과성이 증가하고, 물질 이동 이 용이하게 되어 용매가 세포 안으로 들어가 보다 많은 성분이 세포 밖으로 용출되면서 폴리페놀 함량이 높아진 것으로 보이며 이는 $\mathrm{Han}$ 등(23)의 고압 추출공정이 길어짐 에 따라 수율 또한 증가한다는 보고와 일치하였다. 플라보 노이드 또한 고온고압추출에서 가장 높은 함량을 나타냈으 며 환류냉각추출, 저온고압추출, 상온교반추출 순으로 높 은 함량을 나타내어 폴리페놀과 비슷한 경향을 보였지만 저온고압의추출의 경우에는 상온교반추출과 큰 차이가 나 지 않아 고압의 환경보다는 고온에서 추출하는 방법이 효율 적인 것으로 사료된다.
Table 2. Total flavonoid and total polyphenol contents of the onion peel extracts according to the extraction method

\begin{tabular}{ccccc}
\hline Measurement & $\mathrm{AE}^{1)}$ & $\mathrm{LTPE}^{2)}$ & $\mathrm{RE}^{3)}$ & $\mathrm{SE}^{4)}$ \\
\hline $\begin{array}{c}\text { Polyphenols } \\
\left(\mathrm{mg} \mathrm{GAE}^{5} / \mathrm{g}\right)\end{array}$ & $209.99 \pm 7.08^{7 \mathrm{a} 8)}$ & $176.01 \pm 3.18^{\mathrm{b}}$ & $178.24 \pm 3.89^{\mathrm{b}}$ & $140.14 \pm 5.88$ \\
$\begin{array}{c}\text { Flavonoids } \\
\left(\mathrm{mg} \mathrm{RHE}^{6} / \mathrm{g}\right)\end{array}$ & $25.00 \pm 0.57^{\mathrm{a}}$ & $20.32 \pm 0.80^{\mathrm{c}}$ & $23.30 \pm 0.36^{\mathrm{b}}$ & $20.09 \pm 0.10^{\mathrm{c}}$ \\
\hline
\end{tabular}

${ }^{1)-4} \mathrm{AE}$, autoclave extraction; LTPE, low temperature high pressure extraction; RE, reflux extraction; SE, stirrer extraction.

${ }^{5-6} \mathrm{GAE}$, gallic acid equivalents; RHE, rutin hydrate equivalents.

${ }^{7}$ Values are mean \pm standard deviation of triplicate determinations.

${ }^{8}$ Different superscripts within a row $(\mathrm{a}-\mathrm{d})$ indicate significant differences $(\mathrm{p}<0.05)$.

\section{$\mathrm{DPPH}$ 라디칼 소거활성 및 $\mathrm{ABTS}$ 라디칼 소거활성}

추출방법에 따른 양파껍질의 DDPH 라디칼 소거활성을 측정한 결과는 Fig. 1과 같다. $1 \mathrm{mg} / \mathrm{mL}$ 의 농도에서 $\mathrm{AE}$ 값이 $28.39 \%$ 로 DPPH 라디칼 소거활성이 가장 높게 측정 되었으 며, $\mathrm{RE}(26.07 \%), \mathrm{LTPE}(24.35 \%), \mathrm{SE}(19.53 \%)$ 순으로 높은 활 성을 나타 내었다. 이와 같은 결과는 약용식물류의 총 페놀 함량과 항산화 활성의 상관관계에서 폴리페놀의 함량이 높을수록 항산화 활성이 높다는 보고(24)로 미루어 볼 때, 양파껍질 추출물의 전자공여능이 페놀류에 기인하여 항산 화 활성을 나타내며, 총 폴리페놀 함량이 높을수록 DPPH 라디칼 소거활성도 높다는 Choi 등(25)의 보고와 일치하는 결과를 나타내었다.

$\mathrm{ABTS}$ 와 potassium persulfate와의 반응에 의해 생성된 $\mathrm{ABTS}$ radical(ABTS $\left.{ }^{+} \cdot\right)$ 은 시료에 함유된 항산화성 물질의 항산화력에 의해 전자를 받아 무색의 물질로 환원시키며, 소수성과 친수성 시료 모두에 적용 가능하다(10). 양파껍질 의 추출방법에 따른 ABTS radical 소거활성을 살펴보면 $\mathrm{AE}$ 는 $33.29 \%$, LTPE는 $25.35 \%, \mathrm{RE}$ 는 $26.72 \%$, SE는 $17.45 \%$ 로 나타났다. ABTS 라디칼 소거활성은 DPPH radical 소거 활성과 원리는 동일하지만 $\mathrm{ABTS}$ 는 양이온 라디칼을, $\mathrm{DPPH}$ 는 음이온 라디칼을 소거활성을 측정하는 방법으로 두 방법에 대한 기질과 반응물질과의 결합정도가 달라 추출 물을 이용한 라디칼 소거활성 측정값에서 차이가 나타난다 
는 보고(26)로 미루어 볼 때 DPPH radical 소거활성 결과와 비교 시 폴리페놀 함량에 따른 $\mathrm{LTPE}$ 와 $\mathrm{RE}$ 의 값이 차이를 나타내었다.

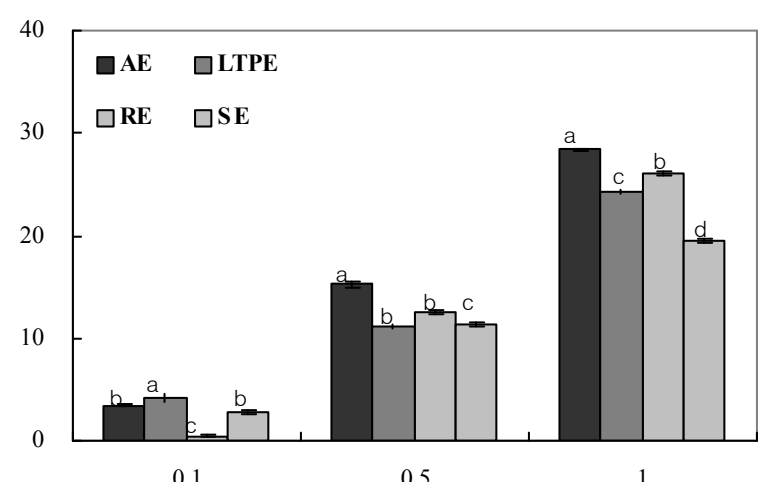

Concentration $(\mathbf{m g} / \mathbf{m L})$

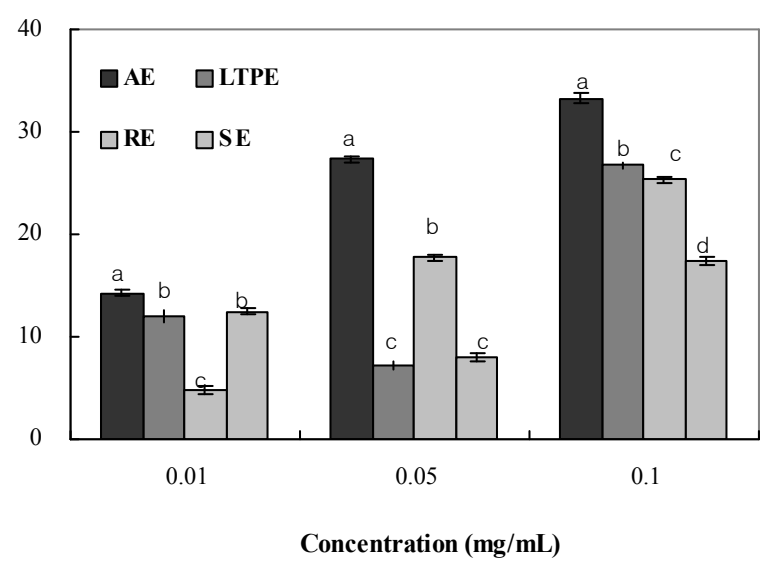

Fig. 1. DPPH and ABTS radical scavenging abilities of the onion peel extracts according to the extraction method.

$\mathrm{AE}$, autoclave extraction; LTPE, low temperature high pressure extraction; RE, reflux extraction; SE, stirrer extraction. Values are mean \pm standard deviation of triplicate determinations. Different superscripts within a column (a-d) indicate significant differences $(\mathrm{p}<0.05)$.

$a$-Glucosidase 저해 효과 및 ACE 저해 효과

추출방법에 따른 양파껍질의 a-Glucosidase 저해 효과를 측정한 결과는 Fig. 2와 같다. a-Glucosidase 저해 효과에서 는 가압가열추출, 저온고압추출, 환류냉각추출, 상온교반 추출이 각각 $58.18 \%, 61.72 \%, 80.24 \%, 59.71 \%$ 의 저해 효과 를 나타냈다. 일반적으로 a-glucosidase는 소장 상피세포의 brush-border membrane에 존재하는 효소로서 다당류의 탄 소화물을 단당류로 분해하는 탄수화물의 소화와 흡수에 필수적인 효소로서 경구혈당강하제로 사용되고 있다(27). $\operatorname{Kim}(5)$ 의 연구에 따르면 양파 추출물은 a-glucosidase에 높 은 저해 효과를 보이며, 양파껍질의 주요 활성성분인 quercetin외에도 양파껍질에 함유되어 있는 여러 성분들이 혈당상승억제에 기여하고 있는 것을 알 수 있다. 따라서
양파껍질 추출물 중 특히 환류냉각추출은 혈중 포도당 농도 의 증가를 억제할 수 있는 효과가 높아 제2형 당뇨와 같은 당질 관련 질병을 위한 치료제 개발을 위한 가장 적합한 추출방법이라 판단된다.

$\mathrm{ACE}$ 는 혈압을 감소시키는 bradykinin을 불활성화시키 는 효소로서 결국 본태성고혈압의 원인이 되고 있으며(28), $\mathrm{ACE}$ 저해제는 $\mathrm{ACE}$ 활성을 저해하여 심혈관실환 및 내혈 관질환 및 고혈압과 관련이 깊은 질환을 치료하는데 사용될 수 있다(29).
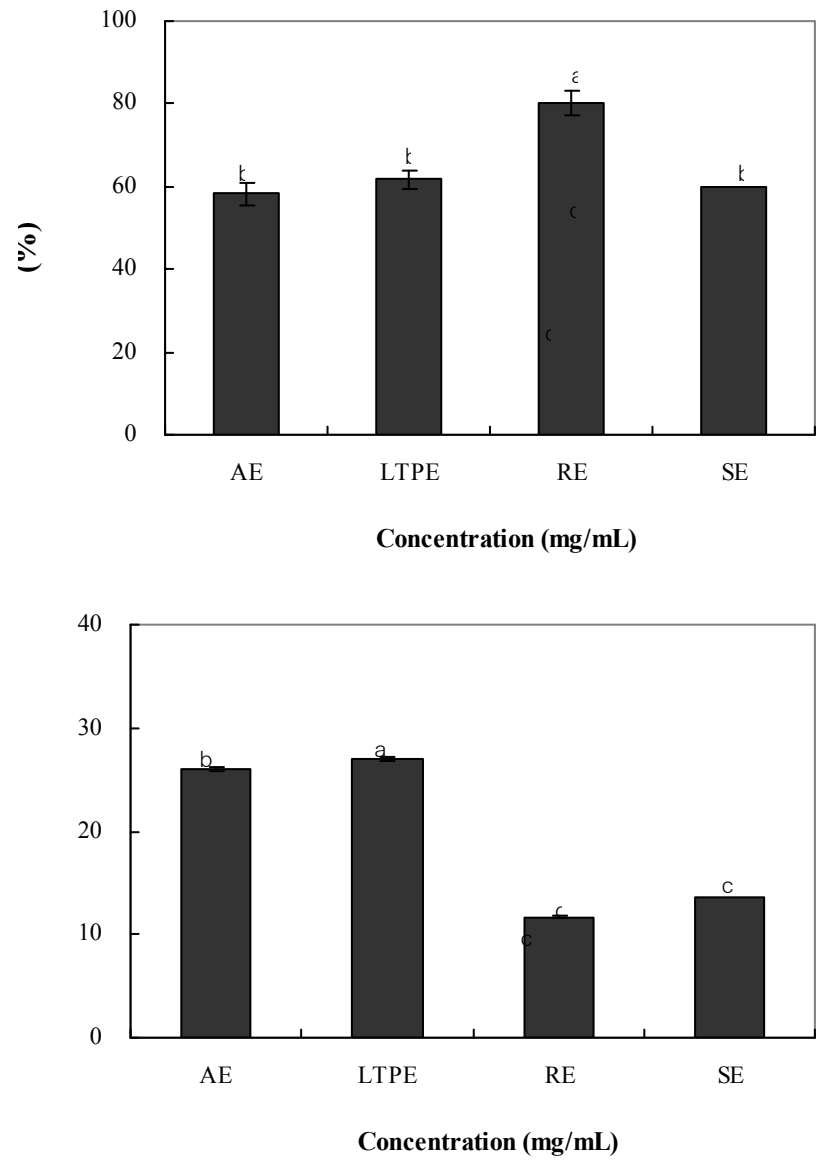

Fig. 2. a-Glucosidase and ACE inhibitory activity and ACE inhibitory activity of the onion peels extracts according to the extraction method $(0.5 \mathrm{mg} / \mathrm{mL})$.

$\mathrm{AE}$, autoclave extraction; LTPE, low temperature high pressure extraction; RE, reflux extraction; SE, stirrer extraction. Values are mean \pm standard deviation of triplicate determinations. Different superscripts within a column (a-d) indicate significant differences $(\mathrm{p}<0.05)$.

추출 방법별 양파껍질추출물의 $\mathrm{ACE}$ 저해활성 조사결과 전체적으로 낮은 저해 효과를 보였지만 추출방법에 따라서 는 저온고압추출(27.05\%)에서 가장 높았고, 다음으로 가압 가열추출(26.04\%), 상온교반추출(13.61\%), 환류냉각추출 $(11.66 \%)$ 순으로 저해 효과를 나타내었다. 이는 추출방법을 달리한 참취 추출물에 관한 $\mathrm{Kim}$ 등(30)의 연구에서 저온고 
압을 실시한 참취 추출물에서 가장 높은 활성을 보는 결과 와 일치하였다. 이러한 효소 활성 저해 효과를 통해 다른 문제점을 유발시키는 저해제들에 대한 양파껍질을 이용한 추가적인 연구와 검증을 통하여 좀 더 다양한 제품들을 개발할 수 있도록 해야 할 것으로 사료된다.

아질산염 소거활성 및 철 이온 $\left(\mathrm{Fe}^{2+}\right)$ 에 대한 chelating 활성 아질산염은 수산물이나 식육제품에 첨가하여 독소 생성 억제와 발색, 산패방지제로 널리 이용되지만 그자체가 독 성을 나타내어 과량 섭취 시 혈액중의 hemoglobin이 산화되 어 met hemoglobin을 형성하여 각종 중독을 일으키는 것으 로 알려져 있으며, 아민류와 아질산염이 반응하면 발암물 질인 nitrosamine을 생성하므로 아질산염 소거활성은 항암 작용을 간접적으로 알 수 있는 지표로 활용된다(31). 추출방 법을 달리한 양파껍질의 아질산염 소거능을 분석한 결과는 Fig. 3과 같다. 아질산염 소거능은 가압가열추출(33.97\%), 환류냉각추출(32.47\%), 저온고압추출(21.86\%), 상온교반
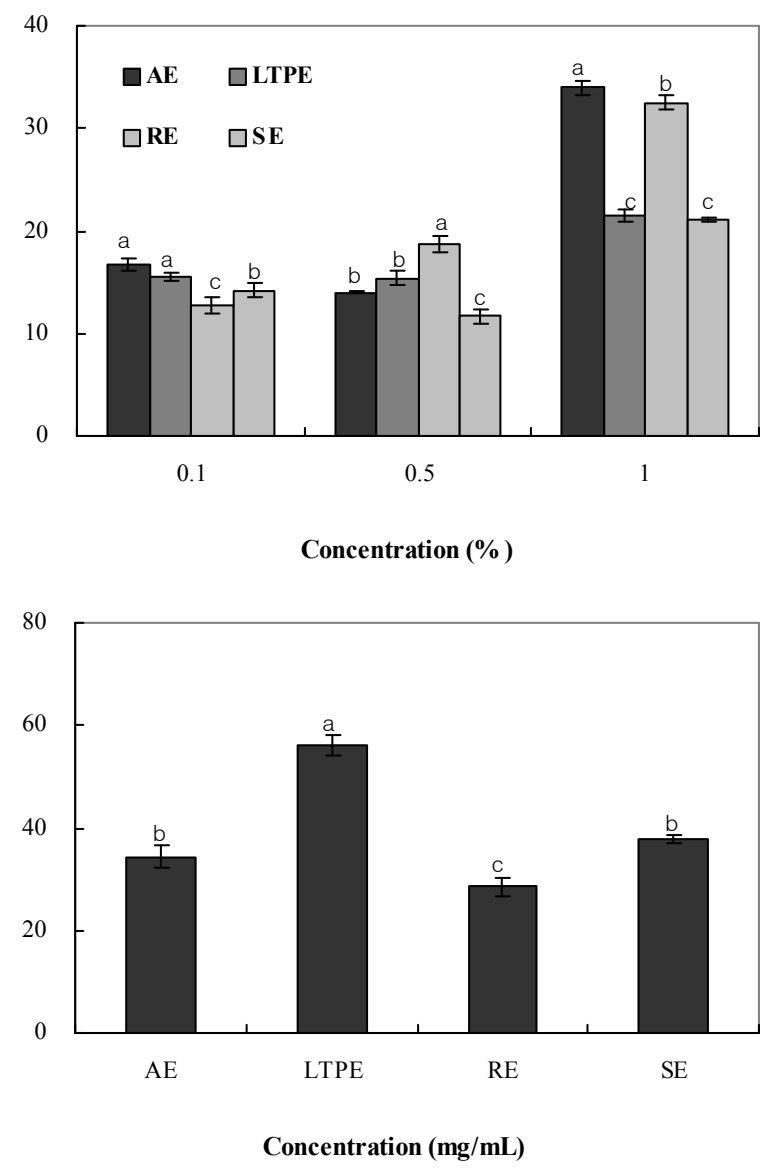

Fig. 3. Nitrite scavenging ability and ferrous ion chelating ability of the onion peels extracts according to the extraction method (5 $\mathrm{mg} / \mathrm{mL}$ ).

$\mathrm{AE}$, autoclave extraction; LTPE, low temperature high pressure extraction; RE, reflux extraction; SE, stirrer extraction. Values are mean \pm standard deviation of triplicate determinations. Different superscripts within a column (a-d) indicate significant differences $(\mathrm{p}<0.05)$.
추출 $(21.71 \%)$ 의 순으로 가압가열추출, 환류추출에서 높은 활성을 나타내었다. Choi 등(32)의 보고에 따르면 polyphenol 과 flavonoid 화합물은 종류에 따라 차이는 있으나 phenol계 유도체들이 nitroso 화합물의 생성을 억제한다고 하여 본 연구에서 추출방법에 따른 소거활성의 차이는 페놀화합물 의 함량 차이에 의한 결과라 판단되며, 유용성분의 함량이 높을수록 라디칼 소거능이 높아지는 것으로 확인 되었다.

한편, 금속 킬레이트 활성 측정은 ferrozine이 $\mathrm{Fe}^{2+}$ 와 반응 하여 복합체를 형성하면 붉은색을 띠게 되는데 이 때 시료 추출물 중에 킬레이트 활성을 가진 성분이 존재하면 $\mathrm{Fe}^{2+}$-ferrozine 복합체 형성을 방해하여 발색이 저해되는 원 리를 이용하였다(31), 추출방법을 달리한 양파껍질의 철 이온 $\left(\mathrm{Fe}^{2+}\right)$ Chelating 을 분석한 결과는 Fig. 3과 같다. 50 $\mathrm{mg} \%$ 의 농도에서 ferrous ion chelating 활성에서는 가압가열 추출(35.88\%), 저온고압추출(54.73\%), 환류냉각추출(28.43\%), 상온교반추출(37.29\%)로 저온고압추출에서 가장 높은 활 성을 나타내었는데 이는 항산화 활성의 경향과는 상반되는 결과로 금속이온을 제거할 수 있는 물질과 radical을 제거할 수 있는 물질의 작용기작의 차이에 따른 결과(33)라 사료되 며, Kwon 등(17)의 추출방법에 따른 쇠비름 추출물의 철 이온 $\left(\mathrm{Fe}^{2+}\right)$ 에 대한 Chelating 활성을 측정하였을 때 저온고 압추출 및 가압가열추출에서 높게 나타난 결과와 일치한다.

\section{요 약}

추출방법에 따른 양파껍질 추출물의 품질 특성 및 생리 활성 특성을 비교하였다. 환류냉각추출의 수율이 $13.21 \%$ 로 가장 높았고, 폴리페놀과 플라보노이드 함량은 가압가 열추출이 가장 높게 나타났다. DPPH 라디칼 소거능 및 ABTS 라디칼 소거능 또한 가압가열추출이 가장 높게 측정 되었다. a-Glucosidase 저해 효과는 $80.24 \%$ 로 환류냉각추출 이 가장 높은 저해 효과를 나타내었고, $\mathrm{ACE}$ 저해 효과는 $27.05 \%$ 로 저온고압추출이 가장 높았다. 아질산염 소거활 성은 가압가열추출이 $33.97 \%$ 로 가장 높았고 다음으로 환류 냉각추출이 $32.47 \%$ 로 높은 활성을 나타내었다. Ferrous ion chelating 효과에서는 저온고압추출이 $54.73 \%$ 로 가장 높은 활성을 나타내었다. 이러한 결과를 종합해 볼 때 가압가열 추출이 소재 활용가치가 높을 것으로 사료되며 천연 항산화 제 및 기능성 증진을 위한 소재로 이용 가능할 것으로 판단 된다.

\section{References}

1. Hwang IT, Hwang JS, Lim HK, Park NJ (2010) Biorefinery based on weeds and agricultural residues. 
Korea J Weed Sci, 30, 340-360

2. Basra AS, Singh B, Malik CP (1994) Amelioration of the effects of ageing in onion seeds by osmotic priming and associated changes inoxidative metabplism. Biol Plantarum, 36, 365-371

3. Rice-Evans CA, Miller NJ, Bolwell PG, Bremley PM, Pridham JB (1955) The relative antioxidant activities of plant-derived polyphenolic flavonoids. Free Radical Res, 22, 375-383

4. Yang EJ (2011) Protective effect of onion-derived quercetin on hippocampal neuronal cell death. Ph D Thesis, Kyungpook University, Korea, p 43-61

5. Kim SH (2011) Anti-hyperglycemic effects and action mechanisms of quercetin and onion extracts. Ph D Thesis, Yonsei University, Korea, p 36-81

6. Kang SK, Kim YD, Hyun KH, Kim YW, Song BH, Shin SC, Park YK (1998) Development of separating techniques on quercetin - related substances in onion (Allium cepa L.) - 1. Contents arid stability of quercetin - related substances in onion. J Korean Soc Food Nutr, 27, 628-686

7. Kwon YJ ,Kim KH, Kim HK (2002) Changes of total polyphenol content and antioxidant activity of Ligularia fischeriextracts with different microwave-assisted extraction conditions. Korean J Food Preserv, 9, 332-337

8. Park JH, Lee HS, Mun HC, Kim DH, Seong NS, Jung HG, Bang JK, Lee HY (2004) Improvement of anticanceractivation of ultrasonificated extracts from Acanthopanax senticosus Harms, Ephedra sinica Stapf, Rubus coreanus Miq. and Artemisia capillaris Thunb. Kor J Med Crop Sci, 12, 273-278

9. Dewanto V, Wu X, Adom KK, Liu RH (2002) Thermal processing enhances the nutritional value of tomatoes by increasing total antioxidant activity. J Agric Food Chem, 50, 3010-3014

10. Abdel-Hameed ESS (2008) Total phenolic contents and free radical scavenging activity of certain egyptian ficus species leaf samples. Food Chem, 114, 1271-1277

11. Blois MS (1958) Antioxidant determination by the use of a stable free radical. Nature, 181, 1199-1200

12. Re R, Pellegrini N, Proteggente A, Pannala A, Yang M, Rice-Evans C (1999) Antioxidant activity applying an improved ABTS radical cation decolorization assay. Free Radic Biol Med, 26, 1231-1237

13. Kim KY, Nam KA, Kurihara H, Kim SM (2008) Potent a-glucosidase inhibitors purified form the red alga gratelou-pia elliptica. Phytochem, 69, 2820-2825
14. Cushman DW, Cheung HS (1971) Spectrophotometric assay and properties of the angiotensin-converting enzyme of rabbit lung. Biochem Pharmacol, 20, $1637-1648$

15. Kato H, Lee IE, Chuyen NV, Kim SB, Hayase F (1987) Inhibition of nitrosamine formation by nondialyzable melanoidins. Agric Biol Chem, 51, 1333-1338.

14. Yen GC, Duhb PD, Tsaia HL (2002) Antioxidant and pro-oxidant properties of ascorbic acid and gallic acid. Food Chem, 79, 307-313

16. Kwon YR, Cho SM, Hwang SP, Kwon GM, Kim JW, Youn KS (2014) Antiocidant, physiological acitivities, and acetylcholinesterase inhibition activity of Portulaca oleracea extracts with different extraction methods. J Korean Soc Food Sci Nutr, 43, 389-396

17. Hwang JK, Kim CT, Hong SI, Kim CJ (1994) Solubilization of plant cell walls by extrusion. J Korean Soc Food Nutr, 23, 358-370.

18. Kang SK, Kim YD, Hyun KH, Kim YW, Seo JS, park YK (1998) Development of separating techniques on quercetin - related substances in onion (Allium cepa L.) - 2. Optimal extracting condition of quercertin - relate substances in onion. J Korean Soc Food Sci Nutr, 27, 687-692.

19. Naczk M, Shahidi F (2003) Phenolic compounds in plant foods : chemistry and health benefits. J Korean Soc Food Sci Nutr, 8, 200-218

20. Nakatani N (1990) Recent advances in the study on natural antioxidants. Nippon Shokuhin Kogyo Gakkaishi, 37, 569-576

21. Rice-Evans C, Miller N, Paganga G (1997) Antioxidant properties of phenolic compounds. Trends Plant Sci, 2, 152-159

22. Han JG, Ha JH, Choi YB, Go JL, Kang DH, Lee HY (2009) The comparison of extraction process for enhancement of immunomodulating activities of ulva pertusa kjellman. Korean J Food Sci Technol, 41, 380-385

23. Kim EY, Baik IH, Kim JH, Kim SR, Rhyu MR (2004) Screening of the antioxidant activity of some medicinal plants. Korean J Food Sci Tchnol, 36, 333-338

24. Choi SY, Lim SH, Kim JS, Ha TY, Kim SR, Kang KS, Hwang IK (2005) Evaluation of the estrogenic and antioxidant activity of some edible and medical plants. Korean J Food Sci Technol, 37, 549-556

25. Kang MH, Park CG, Cha MS, Seong NS, Chung HK, Lee JB (2001) Component characteristics of earch extract prepared by different extract methods from by products 
of glycyrrhizia uralensis. J Korean Soc Food Sci Nutr, 30, 138-142

26. Standl E, Baumgartl HJ, Fŭchtenbusch M (1999) Effect of acarbose on additional insulin therapy in type 2 diabetic patients with late failure of sulphonylurea therapy. Diabetes Obes Metab, 1, 215-220

27. Noh H, Song KB (2001) Isolation of an angiotensin converting enzyme inhibitor from Oenanthe javanica. Agric Chem Biotechnol, 44, 89-99

28. Oh SH, Kim SH, Kim SK, Eaek YJ, Cho KH (1997) Angiotensin- I converting enzyme inhibitor activity of the K-casein fragments hydrolysated by chymosin, pepsin and trypsin. Korean J Food Sci Technol, 29, 1316-1318

29. Kim JW, Youn KS (2014) Polyphenolic compounds, physiological activities, and digestive enzyme inhibitory effect of Aster scaber Thunb. extracts according to different extraction processes. J Korean Soc Food Sci Nutr, 43,1701-1708

30. Na GM, Han HS, Ye SH, Kim HK (2004) Physiological activity of medicinal plant extracts. Korean J Food Preserv, 11, 388-393

31. Choi JS, Park SH, Choi JH (1989) Nitrite scavenging effects by flavonoids and its structure-effect relationship. Arch pharm Res, 12, 26-33

32. Kwon YR, Youn KS (2014) Antioxidant activity and physiological properties of Moringa (Moringa oleifera Lam.) leaves extracts with different solvents. Korean J Food Preserv, 21, 831-837

33. Graf E, Eaton JW (1990) Anticxidant functins of phytic acid. Free Radical Biol Med, 8, 61-69 